A RCHIWA, BIBLIOTEKI

I MUZEA KOŚCIELNE 109 (2018)

https://doi.org/10.31743/abmk.2018.109.12

TOMASZ KRUSZEWSKI* - TORUŃ

\title{
BRONISLAW GUBRYNOWICZ I UFORMOWANIE JEGO WARSZTATU BADAWCZEGO W STACJI NAUKOWEJ PAN W RZYMIE ${ }^{1}$
}

Stacja Naukowa Polskiej Akademii Nauk w Rzymie zgodnie z ostatnią wolą prof. Bronisława Gubrynowicza została obdarowana jego prywatną biblioteką. Ten zasób naukowy i warsztat pracy uczonego nie był dotąd przedmiotem żadnych opracowań naukowych. W publikacjach wspomina się go zwykle krótkim stwierdzeniem, że istnieje i że znajduje się w zasobach rzymskiej biblioteki PAN². Dlatego w artykule podjąłem się próby przyczynkowej charakterystyki tzw. biblioteki Gubrynowicza. Zarysowałem tło historyczno-organizacyjne związane z oddaniem księgozbioru pod opiekę Polskiej Akademii Umiejętności. Uwagę skupiłem na okresie od śmierci Profesora do otwarcia biblioteki w Stacji Rzymskiej w 1939 r. Wątek stricte bibliotekoznawczy, odnoszący się do struktury księgozbioru i jego przeobrażeń po drugiej wojnie światowej, nie został poddany głębszej analizie i zostanie poruszony na łamach mojej innej publikacji.

\section{Organizacja Stacji Naukowej w Rzymie}

Aktywność naukowa Polaków w Rzymie - czy, jak ją poetycko nazywał Maciej Loret, „polskie pielgrzymstwo naukowe” - sięga XVI w., kiedy na polecenie króla Stefana Batorego kopiowano, będące w zasobach archiwów watykańskich, dokumenty dotyczące Polski i Węgier. Z czasem działalność badawcza nabrała bardziej formalnego charakteru, chociaż wciąż niestacjonarnego. Od pierwszej

* Tomasz Kruszewski - dr hab. bibliologii i informatologii; adiunkt w Instytucie Informacji Naukowej i Bibliologii; Uniwersytet Mikołaja Kopernika w Toruniu; e-mail: tomkrus@umk.pl

${ }^{1}$ Artykuł powstał w ramach badań zrealizowanych dzięki stypendium Fundacji Lanckoronskich.

${ }^{2}$ Zob. D. Rederowa, Polska Stacja Naukowa w Rzymie, „Rocznik Polskiej Akademii Umiejętności”, 1992/1993 (1994) s. 225; J. Dybiec, Polska Akademia Umiejętności: 1872-1952, Kraków 1993, s. 65; K. Żaboklicki, 75-lecie Stacji Naukowej w Rzymie, „Nauka”, 2 (2003) s. 152; K. Seroka, Stacja Naukowa Polskiej Akademii Nauk w Rzymie, „Przegląd Polsko-Polonijny”, 4 (2012) z. 1 , s. 163 . 
połowy XIX wieku w Rzymie działały osoby związane z paryskim Wydziałem Historycznym Towarzystwa Literackiego. Uruchomiono wówczas polskie archiwum historyczne. Atrakcyjność pozyskiwanych materiałów, zwłaszcza w kontekście popowstaniowych reperkusji zubażających zasoby krajowych bibliotek i archiwów, przyczyniła się do zorganizowania przez akademickie środowisko krakowskie oraz Akademię Umiejętności kolejnych ekspedycji rzymskich ${ }^{3}$. Skala tych małopolskich przedsięwzięć historiograficznych przewyższała wszystkie inne podobne krajowe inicjatywy ${ }^{4}$. Szczególnie zasłużonym w obszarze organizacyjnym i naukowym był historyk, prof. Stanisław Smołka. To on, przygotowując projekt, postulował założenie Stacji Naukowej w Rzymie. Smołka wnioskował też do Komisji Historycznej Akademii Umiejętności o stypendium pobytowe dla Bronisława Gubrynowicza, podówczas doktora. Tenże w latach 1895-1896 badał we włoskich zasobach biblioteczno-archiwalnych dzieje Polski w okresie Jana Kazimierza ${ }^{5}$.

Ekspedycja Rzymska przez wiele lat polegała na czasowych pobytach uczonych we Włoszech, jednak stałej bazy nie organizowano. Taką szansę otworzyła dopiero współpraca przemianowanej na Polską Akademię Umiejętności oraz takich postaci, jak Maciej Loret i Konstanty Skimrut ${ }^{6}$ z mieszkającym w Rzymie hrabią Józefem Michałowskim. Michałowski w 1921 r. podarował Ekspedycji prywatną bibliotekę - składającą się głównie z dzieł historycznych. Ulokowano ją w siedzibie polskiej fundacji, tj. w Hospicjum św. Stanisława przy via delle Oscure $15 \mathrm{w} \mathrm{Rzymie} \mathrm{R}^{7}$. Ów księgozbiór stał się osnową dla rodzącej się instytucji naukowej w stolicy Włoch oraz zrębem książnicy rozbudowywanej w kolejnych latach o zakupy i dary. Wśród późniejszych darczyńców znaleźli się m.in. Karol, a następnie Karolina Lanckorońscy - darczyńcy słynnej Fototeki, Stanisław Badeni, który Stacji przekazał zbiór po Maxie Dvořáku ${ }^{8}$. Jednocześnie niedostatecznie duże zasoby lokalowe, nie dość klarowne stosunki polityczne między Włochami a Polską w okresie przed przewrotem majowym, skutkujące niepewnością funkcjonowania organizacji na obczyźnie oraz przede wszystkim zły stan techniczny budynku Hospicjum św. Stanisława i konieczność przeprowadzenia jego remontu (to właśnie biblioteka Stacji nadwyrężała w największym zakresie wytrzymałość gmachu), nakazywały poszukiwania większej powierzchni magazynowo-administracyjnej w stolicy Włoch. Hospicjum dopiero kilka lat wcześniej odzyskane z rąk rosyjskich, nakładało poza tym różne ograniczenia, jak choćby wprowadzone pod koniec lat 30. XX wieku dwudziestoosobowe limity gości podczas odczytów organizowanych w Stacji. Ciasnota panowała ponadto w kilku pomieszczeniach zajmowanych przez Stację na górnej kondygnacji Hospicjum. Z tych organizacyjno-lokalowych powodów inicjujące powstanie biblioteki dary książ-

${ }^{3}$ Rederowa, Polska Stacja, s. 188-193.

${ }^{4}$ Por. Dybiec, Polska Akademia, s. 64.

${ }^{5}$ Rederowa, Polska Stacja, s. 196.

${ }^{6}$ J. Piskurewicz, Ośrodki upowszechniania nauki polskiej we Włoszech 1918-1939, „Kwartalnik Historii Nauki i Techniki”, 2 (1995) s. 57-58.

${ }^{7}$ Rederowa, Polska Stacja, s. 217-218.

${ }^{8}$ Zob. Dybiec, Polska Akademia, s. 65. 
kowe Michałowskiego, Gubrynowicza i inne przez kilka lat przechowywano bez możliwości ich ekspozycji.

Okazja pozyskania większej siedziby pojawiła się w drugiej połowie lat 30 . i dotyczyła Palazzo Doria. Nową siedzibę przy ówczesnej via della Fede (obecnie vicolo Doria 2) Stacja otworzyła oficjalnie w styczniu 1939 r. ${ }^{9}$ Ulokowana w niej biblioteka, nie licząc kolekcji gubrynowiczowskiej oraz prac z działu historia sztuki, została uporządkowana już kilka miesięcy wcześniej, bo z końcem sierpnia 1938 r. ${ }^{10}$ Doprowadzenie do porządku dwóch wymienionych kolekcji - jak się wkrótce okazało - nie było już tak proste.

W czasie wojny zasoby Stacji nie uszczupliły się, ponieważ zostały zdeponowane w Watykanie, instytucja zaś znalazła się pod opieką Stolicy Apostolskiej ${ }^{11}$. Po zakończeniu działań drugiej wojny światowej, status Stacji PAU ulegał dynamicznym przeobrażeniom. Kuratelę sprawowały kolejno: brytyjska Interim Treasury Commission, Ambasada Polska w Rzymie, Polska Akademia Umiejętności, wreszcie Polska Akademia Nauk, która w 1957 r. otworzyła dla publiczności placówkę jako Stacja Naukowa PAN w Rzymie. Po wojnie możliwości pracy w Stacji pozbawiony został również fundator i jej przedwojenny dyrektor - Józef Michałowski. Zastąpił go prof. Kazimierz Bulas. Potem zaś przez niemal 30 lat prowadził Stację prof. Bronisław Biliński ${ }^{12}$. Kolejni dyrektorzy kontynuowali formę organizacyjną i merytoryczną Stacji sformułowaną w jej PAN-owskim okresie.

W 2017 r. szacuje się, że cały księgozbiór Stacji liczy około 36.000 tytułów ${ }^{13}$.

\section{Bronisław Gubrynowicz (1870-1933)}

Wiele wskazuje na to, że zainteresowania naukowe Bronisława Gubrynowicza pojawiły się w odpowiedzi na charakter środowiska, w którym dorastał ${ }^{14}$. Urodził się we Lwowie w rodzinie arystokratycznej, a zarazem rodzinie znanej na Kresach ze swojej działalności krzewiącej polską kulturę literacką. Jako syn znaczącego na rynku wydawcy (ojciec Władysław był twórcą m.in. serii literackich Biblioteka Powieści oraz Pamiętniki i Podróże ${ }^{15}$ ) spotykał w domu twórców

${ }^{9}$ D. Wronikowska, Fototeka Karola Lanckorońskiego w Stacji Naukowej PAN w Rzymie, Rzym 2004 (materiał niepublikowany - w zasobach Biblioteki Stacji Naukowej PAN w Rzymie).

${ }^{10}$ Zob. Archiwum Stacji Naukowej PAN w Rzymie (dalej: ASN PAN). Odpis pisma J. Michałowskiego z dn. 4.09.1938, Zespół: Korespondencja Stacji 1938-1940, Część korespondencji i dokumentacji dotyczącej rzymskiej biblioteki znajduje się również w Archiwum Nauki PAN i PAU w Krakowie (dalej: AN PAU)

${ }^{11}$ Np. Żaboklicki, 75-lecie Stacji, s. 152.

${ }^{12}$ Szerzej o powojennych kłopotach organizacyjnych w Stacji: Wronikowska, Fototeka Karola Lanckorońskiego; Żaboklicki, 75-lecie Stacji, s. 152.

${ }^{13}$ Jest to stan szacunkowy, ponieważ część zbiorów nie została nadal zinwentaryzowana.

${ }^{14}$ Niemal cały numer „Ruchu Literackiego” z 1933 r. (nr 5-6) został poświęcony życiu i twórczości Gubrynowicza, toteż w tym artykule przedstawiono jedynie te fakty, które są związane $\mathrm{z}$ tematyką opracowania.

${ }^{15}$ Biogramy uczonych polskich: materiały o życiu i działalności członków AU w Krakowie, TNW, PAU, PAN: Cz. I: Nauki społeczne, z. 1: A-J, opr. A. Śródka, P. Szczawiński, Wrocław 1983, s. 439. 
literatury pięknej, jak i jej mecenasów oraz zaangażowanych czytelników. Trudno więc dziwić się, że podjął studia uniwersyteckie z zakresu literaturoznawstwa i historii - najpierw we Lwowie pod kierunkiem Romana Pilata w latach 18821892, potem w 1893 r. w Berlinie ${ }^{16}$. To Roman Pilat, rektor Uniwersytetu Lwowskiego, członek Akademii Umiejętności w Krakowie, Towarzystwa Literackiego im. Adama Mickiewicza, zdeterminował profil historycznoliterackich zainteresowań Gubrynowicza, które podążyły głównie w kierunku literatury romantycznej, choć znajdowały też niekiedy upust $\mathrm{w}$ innych miejscach ${ }^{17}$. Wpływ na to miała bez wątpienia otaczająca go kultura akademicka. Dość dodać, że wśród uczniów Pilata znajdowali się: Ludwik Finkel, Wiktor Hahn, Wilhelm Bruchnalski czy Andrzej Gawroński. Wiedząc o tych związkach, nie powinna zastanawiać pozornie przypadkowa struktura księgozbioru Gubrynowicza, obfitującego w publikacje z zakresu bibliologii oraz o cechach bibliofilskich. Ponadto tematyka tych zbiorów była pokrewna niektórym formom działalności zawodowej uczonego, który był zatrudniony w Zakładzie Narodowym im. Ossolińskich we Lwowie, pracując najpierw na stanowisku skryptora literackiego, potem kustosza ${ }^{18}$.

Księgozbiór był jednak zdominowany literaturą piękną i jej historyczno-analitycznymi oraz edytorskimi opracowaniami, stanowiącymi główny przedmiot zainteresowań badawczych B. Gubrynowicza. Ta tematyka oczywiście była związana z zasadniczym obszarem aktywności zawodowej, potem naukowej, co znalazło odbicie w instytucjach zatrudniających B. Gubrynowicza: Gimnazjum im. Franciszka Józefa we Lwowie, jako nauczyciela języka polskiego, Uniwersytecie im. Jana Kazimierza we Lwowie i przede wszystkim Uniwersytecie Warszawskim, gdzie począwszy od 1920 r. aż do śmierci piastował funkcję kierownika II Katedry Historii Literatury Polskiej. W tej uczelni jako profesor zwyczajny prowadził wykłady z historii literatury polskiej. Tam też współorganizował bibliotekę podręczną polonistyki ${ }^{19}$. Wykłady uniwersyteckie były pochodną pracy badawczo-pisarskiej. Ta na dobre - nie licząc drobnych szkiców - rozpoczęła się już w 1898 r. i to od razu jednym z najważniejszych, jeśli nie najważniejszym dziełem uczonego, tj. Albumem Piotra Moszyńskiego (Lwów: nakł. Towarzystwa Literackiego im. A. Mickiewicza) - wcześniej nieznanym, a zawierającym pierwsze - jak się określa - jedyne wiarygodne redakcje mickiewiczowskich sonetów.

Jako autor w 1904 r. B. Gubrynowicz pojawił się z opracowaniem Romans w Polsce za czasów Stanisława Augusta ${ }^{20}$ wydanym w oficynie współzarządzanej przez ojca uczonego. Rozprawa dedykowana rodzicom wskazuje, jak silne piętno na życie zawodowe Bronisława wywarła rodzina. Nawiasem mówiąc, jego dbałość o relacje interpersonalne nie ograniczała się chyba do najbliższych, ale

${ }^{16}$ Z. Łempicki, Zmarli czlonkowie: ś.p. Bronisław Gubrynowicz (1870-1933), „Rocznik Towarzystwa Naukowego Warszawskiego", 27 (1934), s. 147-148.

${ }^{17}$ Zob. Z. Łempicki, Twórczość naukowa Bronisława Gubrynowicza na tle epoki, „Ruch Literacki”, 5-6 (1933), s. 98.

${ }^{18}$ Biogramy uczonych polskich, s. 439.

${ }^{19}$ Zob. Z. Brochocka, Profesor Bronisław Gubrynowicz w Uniwersytecie Warszawskim, „Ruch Literacki", 5-6 (1933), s. 109.

${ }^{20}$ Lwów: Gubrynowicz i Schmidt, 1904. 
wykraczała poza rodzinę. Jeden z jego uczniów Stanisław Łempicki w nocie żałobnej pisał:

Działalność naukowa ś.p. prof. Gubrynowicza nie wyczerpywała się w pracach i rozprawach, które sam pisał, ale obejmowała także i te, do których podnietę dawał swoim uczniom, a niewątpliwie także i te, których ukazanie się umożliwiał. Jako profesor interesował się serdecznie nie tylko pracą, ale i życiem swoich uczniów ${ }^{21}$.

Z innych ważniejszych prac B. Gubrynowicza trzeba wymienić wspólne z Wiktorem Hahnem wielotomowe krytyczne wydanie dzieł Słowackiego (były też pomniejsze opracowania jego twórczości), niepełną monografię (oraz opracowania przyczynkarskie) Kazimierza Brodzińskiego ${ }^{22}$, monografie Antoniego Małeckiego $^{23}$ i Józefa Maksymiliana Ossolińskiego ${ }^{24}$. Z kolei jego zasługi w obszarze animacji ruchu pisarsko-wydawniczego to redagowanie „Pamiętnika Literackiego" oraz inauguracja i patronat innemu czasopismu, mianowicie „Ruchowi Literackiemu" (które po śmierci B. Gubrynowicza przejął jego uczeń Piotr Grzegorczyk $^{25}$ ), a także serii Biblioteka Pamiętnika Literackiego ${ }^{26}$. Łącznie B. Gubrynowicz pozostawił po sobie około 450 prac $^{27}$.

Aktywność badawcza i organizacyjna B. Gubrynowicza to również przynależność do towarzystw naukowych w Warszawie i Lwowie oraz do krakowskiej Polskiej Akademii Umiejętności ${ }^{28}$. Przytaczany Łempicki tak wspominał swojego nauczyciela:

Sam człowiek wielkiej pracy, do końca życia gorliwie oddający się nauce i wzbogacający pilnie i sumiennie zakres swojej wiedzy, ażeby go potem wspaniałomyślnie innym udzielić, nie szczędził trudu w zbiorowych wysiłkach inicjatyw społecznych i naukowych ${ }^{29}$.

Zwłaszcza ta ostatnia organizacja wywarła wpływ na B. Gubrynowicza. To dzięki jej stypendium miał sposobność prowadzenia badań w Archiwum Watykańskim w 1894 r. i to jej rzymskiemu oddziałowi zapisał w testamencie prywatną bibliotekę, która jak za życia uczonego, tak po jego śmierci służyć miała wielu badaczom.

${ }^{21}$ Łempicki, Zmarli, s. 148. Zob. też wspomnienia zamieszone na łamach poświęconego

B. Gubrynowiczowi numeru „Ruchu Literackiego” z 1933 roku (nr 5-6).

${ }^{22}$ Życie i dzieła, Lwów: Gubrynowicz i Syn, 1917.

${ }^{23}$ Lwów: Zakład Narodowy im. Ossolińskich, 1920.

${ }^{24}$ Lwów: Zakład Narodowy im. Ossolińskich, 1928.

${ }^{25}$ J. Starnawski, Piotr Grzegorczyk (17 listopada 1894-20 maja 1968), „Pamiętnik Literacki”, 2 (1969) s. 409.

${ }^{26}$ Biogramy uczonych polskich, s. 440.

${ }^{27}$ Ich zestawienia wzbogaconego o wykaz wykładów uniwersyteckich dokonał w roku śmierci badacza Piotr Grzegorczyk, publikując je w „Ruchu Literackim” oraz w formie samodzielnej nadbitki, zob. P. Grzegorczyk, Bibljografja prac Prof. Bronisława Gubrynowicza, „Ruch Literacki”, 5-6 (1933) s. 114-128.

${ }^{28}$ Biogramy uczonych polskich, s. 440.

${ }^{29}$ Lempicki, Zmarli, s. 148. 


\section{Biblioteka Gubrynowicza - historia kolekcji po śmierci właściciela do jej powtórnego otwarcia (1933-1939)}

Prywatna biblioteka Bronisława Gubrynowicza powstawała w sposób typowy dla tego rodzaju kolekcji. Przede wszystkim była odzwierciedleniem zainteresowań zawodowych oraz prywatnych i gromadzona latami jako warsztat podręczny badacza. Książki były kupowane w handlu księgarskim i antykwarycznym, a także pozyskiwane w drodze wymiany oraz otrzymywane w darach od autorów, przyjaciół, osób ubiegających się o protekcje, przyjaźń itd. Nie bez wpływu na rozrost kolekcji miały lwowskie kontakty Gubrynowiczów - samego profesora, jak i jego ojca, przypomnijmy, wydawcy i prowadzącego salon literacki. Nota bene $\mathrm{w}$ toku przyszłych badań ciekawe byłoby sprawdzenie, na ile biblioteka wędrowała za uczonym ze Lwowa do Warszawy i z powrotem do Lwowa, gdzie Gubrynowicz zmarł i skąd po jego śmierci udała się w drogę do Italii.

Tak więc, księgozbiór znalazł się w stolicy Włoch dzięki zapisowi testamentowemu B. Gubrynowicza, który zobowiązał rodzinę do przekazania go Stacji Rzymskiej PAU. Dlaczego właśnie obdarowano tę instytucję? Złożyło się na to zapewne kilka czynników. Wydaje się, że przede wszystkim wpływ na taką decyzję miało to, że pięć lat przed śmiercią, tj. w 1928 r. Gubrynowicz stał się członkiem korespondentem Wydziału Filologicznego PAU, której to organizacji Stacja Rzymska była częścią ${ }^{30}$. Wcześniej jednak był członkiem już wspomnianej Ekspedycji Rzymskiej wspierającej młodych badaczy prowadzących swoje projekty W archiwach włoskich i watykańskich. Wśród nich pojawiali się późniejsi wybitni przedstawiciele polskiej nauki, jak: Wiktor Czermak, Feliks Konieczny, Feliks Kopera, Michał Loret czy Jan Ptaśnik ${ }^{31}$.

W efekcie tych czynników oraz - biorąc pod uwagę zapisy zachowanej w Rzymie i Krakowie korespondencji archiwalnej między rodziną Gubrynowiczów a przedstawicielami PAU, w połowie 1933 r. Michałowskiego odwiedziła wdowa po profesorze Gubrynowiczu ze wstępnym zamiarem przekazania Stacji zbioru polonistycznego wraz z meblami, który według ówczesnej relacji miał liczyć 4.000 tomów. Warunkiem było umieszczenie kolekcji w osobnej sali i nadanie jej imienia zmarłego. Decyzja o przyjęciu daru miała być podjęta przez władze PAU, o co Michałowski gorąco zabiegał, wskazując na profity dla Stacji i dla kultury polskiej, która nie może utracić tego cennego materiału. Obawy wynikały z tego, że rodzina Gubrynowiczów rozważała ofiarowanie kolekcji Uniwersytetowi w Rzymie. Stąd też Michałowski zapewniał, że nie będzie dla Stacji żadnym problemem wydzielenie osobnego pomieszczenia pod gubrynowiczowską spuściznę $^{32}$. Z końcem 1934 r. jej dyrektor był pełen optymizmu w zakresie lokalizacji zbioru, miał nawet gotowe pomysły co do oferowanych mu mebli potrzebnych do

${ }^{30}$ Członkowie Akademii Umiejętności oraz Polskiej Akademii Umiejętności: 1872-1952, opr. E. H. Nieciowa, Wrocław 1973, s. 64.

${ }^{31}$ Dybiec, Polska Akademia, s. 59.

${ }^{32}$ ASN PAN, zespół: Korespondencja z Sekretarzem Generalnym PAU 1934, Nr 15/33, Korespondencja J. Michałowskiego z dn. 18.07.1933; ASN PAN, Odpis pisma Międzynarodowych Ekspedytorów C. Hartwig. Oddział we Lwowie z dn. 30.11.1934. 
ustawienia książek ${ }^{33}$. Jak się wkrótce okazało, optymizm było mocno na wyrost wobec piętrzących się w kolejnych latach trudności lokalowych.

Po ustaleniach natury formalnej między władzami PAU a rodziną Gubrynowiczów i sporządzeniu umowy darowizny ${ }^{34}$, pod koniec listopada 1934 r. firma spedycyjna C. Hartwig zorganizowała ze Lwowa (księgozbiór do transportu przygotowano najpewniej w Zakładzie Narodowym im. Ossolińskich) do Rzymu, ubezpieczony na sumę 10.000 zł transport 19 skrzyń książek, o łącznej wadze blisko dwóch ton ${ }^{35}$. Nim przesyłka trafiła do docelowego magazynu w bibliotece Stacji, przejściowo całość została na prośbę Michałowskiego umieszczona w Ambasadzie Polskiej w Rzymie przy via Caesare Beccaria ${ }^{36}$. Miało to być związane z pracami adaptacyjnymi przy via delle Oscure.

Wg szacunków pracującego wówczas w Stacji personelu, biblioteka Gubrynowicza liczyła około 3.000-3.500 woluminów, głównie dzieł literatury pięknej, jej edytorskich, językoznawczych i historyczno-literackich analiz. Była też pewna liczba prac historycznych, bibliologicznych, czasopism literackich i encyklopedii. Najbardziej miarodajne przy weryfikacji są tutaj inwentarze. Pierwszy 119. stronicowy inwentarz spisany ręcznie na kartach formatu A4, zapewne w połowie lat 30. ubiegłego wieku (w Archiwum Stacji dostępna jest też przedwojenna kopia w maszynopisie), zawierał 3.194 opisy tytułów wydawnictw zwartych i ciągłych. Pod jedną pozycją inwentarzową mogło znajdować się wydawnictwo wielotomowe lub rocznik, a nawet kilka roczników periodyku. Opisy były sporządzane prawdopodobnie na podstawie oględzin woluminów w kolejnych transportowych kartonach i zawierały zwykle podstawowe dane bibliograficzne: nazwisko i imię autora, tytuł pracy, miejsce i rok wydania. Niekiedy dodawano numer wydania publikacji ${ }^{37}$.

Najbardziej jednolitym i pełnym jest przedwojenny ręcznie sporządzony inwentarz, składający się z ośmiu, około 70. stronicowych zeszytów w formacie A4. Pięć kolejno ponumerowanych zeszytów odnotowuje monografie. Łącznie liczą 2.115 jednostek inwentarzowych sprawdzonych podczas skontrum sprzed kilkunastu lat, a wcześniej m.in. w 1951 r. Kontrole wykazały kilkadziesiąt braków. To chyba niemało, zważywszy na bezpieczne dla kolekcji czasy drugiej wojny światowej. Należy jednak oczekiwać, że część z tych pozycji zostanie odnaleziona w trakcie porządkowania całej biblioteki Stacji - tak się sukcesywnie dotąd działo.

Jeden zeszyt z omawianego inwentarza to spis broszur, a dwa ostatnie to zestawienia książek według kolokacji, z podanymi jednocześnie numerami regałów według schematu w stylu: „1 G V”. Znajdują się tam adnotacje ze skontrum prze-

${ }^{33}$ ASN PAN, zespół: Korespondencja z Sekretarzem Generalnym PAU 1934, Nr 31/34, Odpis pisma J. Michałowskiego z dn. 19.11.1934.

${ }^{34}$ AN PAU, sygn. Nr I-135. Umowa darowizny.

${ }^{35}$ M.in. korespondencja między St. Kutrzebą a J. Michałowskim z lutego 1935 r. dot. zwrotu kosztów spedycji poniesionych przez Michałowskiego, ASN PAN. Zespół: Korespondencja Stacji 1936-1937.

${ }^{36}$ ASN PAN, zespół: Korespondencja z Sekretarzem Generalnym PAU 1934, Pismo St. Kutrzeby z dn. 13.11.1934.

${ }^{37}$ ASN PAN, Inwentarz Bibljoteki Daru Bronisława Ludwika Gubrynowicza. 
prowadzonego w $1954 \mathrm{r}$. W istocie jednak ten spis to ułożone pozycje książkowe według serii wydawniczych, tudzież wydawców, a więc w układzie mało funkcjonalnym przy melioracji zbiorów. Czytelność inwentarza zaburza fakt, że w rejestrze kolokacji dopisano w 1957 r. około 380 pozycji wydanych w latach 40. i 50. $\mathrm{XX}$ wieku, mających być uzupełnieniem w miejsce tych prac, które zostały wydzielone do wysyłki do Biblioteki Kórnickiej. Dla broszur sporządzono w 2000 r. osobną księgę inwentarzową. Wprowadzone do niej tytuły zostały jednocześnie wykreślone z głównej księgi inwentarzowej biblioteki Stacji, co powoduje jedynie dodatkowe trudności organizacyjne $\mathrm{w}$ jednostce i tak doświadczonej wieloletnimi zaniedbaniami w zakresie nadzoru bibliotekoznawczego. Dopiero od kilku lat w Stacji pracuje bibliotekarz z pełnym wykształceniem akademickim w tej dziedzinie wiedzy. Wcześniej były to osoby przyuczone do zawodu, stąd realizowano różne inicjatywy, nierzadko dalekie od dobrych praktyk bibliotekarskich.

Jak wspomniałem, ofiarowany zbiór był stosunkowo jednorodny i zachowany w bardzo dobrym stanie. Nic więc nie wskazywało na kilkuletnie perturbacje związane z rzeczywistym włączeniem go zasobów Stacji, a kilkudziesięcioletnie z pełnym skatalogowaniem i utrzymaniem jako odrębnej kolekcji.

Pierwotnie zarysowane przez dyrektora Stacji Michałowskiego trudności wyglądały na drobne i przejściowe. Pierwsza miała podłoże finansowe, druga organizacyjne, choć zdaje się i w niej niedostatki budżetowe odgrywały pewną rolę. Zwolnienie z opłacenia cła za wwiezienie księgozbioru do Włoch wymagało pewnych zabiegów dyplomatycznych, lecz dzięki wsparciu polskiego ambasadora w Rzymie istniała nadzieja na szybkie załatwienie sprawy. Tymczasem ciągnęła się ona przez kilka lat ${ }^{38}$. Jeszcze gorzej było $\mathrm{z}$ działaniami logistyczno-bibliotekarskimi. W jednym z pierwszych w tej sprawie pism Michałowskiego do prezesa Polskiej Akademii Umiejętności, prof. Stanisława Kutrzeby nie wyglądało to na duży kłopot. Michałowski po uzgodnieniach z architektem uznał, że najbezpieczniejsze będą dwie lokalizacje w odrębnych pokojach, tak aby nie ucierpiała na tym konstrukcja budynku, nie będącego w najlepszym stanie. Były to jednak bardzo wstępne przymiarki, bo jak się wkrótce okazało, Stacja miała zostać przeniesiona do nowej siedziby, a sam Michałowski nie miał pełnego wyobrażenia wielkości darowanej biblioteki. Być może jego wątpliwości pojawiły się wskutek oszacowania rozmiarów dotychczasowych mebli, w których ulokowane były książki (Michałowski nawet prosił wdowę po uczonym, by ta mebli do Rzymu nie wysyłała) i być może dlatego zabiegał u Kutrzeby o zatrzymanie transportu ze Lwowa, dopóki sam nie dokona oględzin daru ${ }^{39}$.

Nie było więc dane bibliotece Gubrynowicza zaistnieć w Hospicjum św. Stanisława, a rozlokowania kolekcji w nowej siedzibie Stacji zlecono Aleksandrowi Kołtońskiemu ${ }^{40}$. Z pewnością nie czynił tego w pojedynkę, lecz w porozumieniu

${ }^{38}$ ASN PAN, zespół: Korespondencja z Sekretarzem Generalnym PAU, Nr 9/38, Robocza wersja pisma J. Michałowskiego z dn. 11.03.1938.

${ }^{39}$ ASN PAN, zespół: Korespondencja z Sekretarzem Generalnym PAU 1934, Odpis pisma J. Michałowskiego z dn. 18.07.1934, Nr 25/34.

${ }^{40}$ Zob. B. Biliński, Biblioteca e Centro di Studi a Roma dell'Accademia Polacca delle Scienze nel 50 Anniversario della Fondazione, 1927-1977, Wrocław 1977, s. 88. 
i z udziałem Michałowskiego, który czas na odpoczynek i poratowanie zdrowia uzależniał właśnie od prac bibliotekarskich przy zbiorze Gubrynowicza ${ }^{41}$. Barbara Sordylowa wskazuje ponadto na prof. Władysława Floriana, który miał w 1939 r. porządkować księgozbiór oraz sporządzić używany jeszcze w latach dwutysięcznych katalog kartkowy ${ }^{42}$.

Wkład w adaptację księgozbioru do potrzeb biblioteki, a więc jego udostępnienie publiczności, wniósł syn darczyńcy - Adam Gubrynowicz (1906-2000), który w latach 30 . ubiegłego wieku był m.in. attaché honorowym ambasady RP w Rzymie. Jako polski dyplomata był jeszcze aktywny przez kilka lat po wojnie, aż do 1949 r., kiedy poprosił o azyl polityczny na Zachodzie. Z kolei jako mecenas kultury był znany przede wszystkim lokalnie na Podkarpaciu. Ufundował m.in. witraże dla XVIII w. kościoła w Zagórzu ${ }^{43}$, niedaleko którego - w Porażu - rodzina baronów Gubrynowiczów posiadała zamek z majątkiem. Warto dodać, że w tej zagorskiej świątyni znajduje się również epitafium upamiętniające Bronisława Gubrynowicza, a na zagorskim cmentarzu kaplica grobowa Gubrynowiczów z płytą nagrobną Bronisława ${ }^{44}$.

Adam Gubrynowicz był żywo zainteresowany wszelkimi sprawami wpływającymi na dobrostan kolekcji ${ }^{45}$. Przykładowo, ponosił koszty usług introligatorskich w jednej z rzymskich pracowni. Dzięki niemu w latach 1939-1940 w zakładzie introligatorskim Giulio Innocenzi wtórnie oprawiono kilkaset woluminów ${ }^{46}$. Były to przede wszystkim skromne oprawy ćwierćpłócienne lub z innymi okleinami introligatorskimi imitującymi skórę, oklejane papierem marmurkowym lub we wzory geometryczne. Grzbiety wyposażano w naklejki ze złotym liternictwem i bordiurami.

Uwagę A. Gubrynowicz przykładał także do rozlokowania zbiorów ojca i ich katalogowania, o czym pisał w korespondencji do Michałowskiego praktycznie od początku obecności zbiorów w Stacji. Gdy tylko otrzymał potwierdzenie dotarcia transportu do Rzymu zadeklarował, że w ciągu mniej niż miesiąca odwie-

${ }^{41}$ ASN PAN, zespół: Korespondencja Stacji 1938-1940, Robocza wersja pisma J. Michałowskiego z dn. 11.03.1938.

${ }^{42}$ Za: A. Szabat, Biblioteka Stacji Naukowej Polskiej Akademii Nauk w Rzymie, Łódź 1996, s. 53, mps. (Praca magisterska pod kier. prof. dr hab. B. Sordylowej; materiał niepublikowany w zasobach Biblioteki Stacji Naukowej PAN w Rzymie).

${ }^{43}$ J. Tarnawski, Witraże w zagórskim kościele, „Verbum: miesięcznik parafii pw. Wniebowzięcia NMP w Zagórzu", 11 (2004) s. 7-8.

${ }^{44}$ E. Śnieżynska-Stolotowa, F. Stolot, Katalog zabytków sztuki: województwo krośnieńskie: Lesko, Sanok, Ustrzyki Dolne i okolice, Warszawa 1982, s. 156.

${ }^{45} \mathrm{~W}$ zasobach archiwalnych AN PAU w Krakowie zachowała się korespondencja między członkami rodziny Gubrynowiczów, a władzami PAU (Kutrzeba) oraz Stacji Rzymskiej (Michałowski), wskazująca na liczne nieporozumienia, a czasami konflikty między stronami. Wprawdzie nie miały one większego związku z tempem prac przy uruchomieniu biblioteki, jednak ukazują szereg osobistych krytycznych ocen sytuacji i stron w sprawie, co nie pozostawało bez wpływu na pogarszającą się atmosferę współpracy.

${ }^{46}$ ASN PAN, zespół: Teczka inwentarzowa, Rachunki z Legatoria di libri Giulio Innocenzi, Via Urbana 157, Roma. 
dzi placówkę, „by dokończyć rozmieszczania i ustawiania biblioteki” ${ }^{47}$. W tym samym liście prosił jednocześnie o informacje, czy należy skompletować zbiory o jakieś pozycje, które sam zadeklarował przywieźć do stolicy Włoch.

A. Gubrynowicz nabywał dla Stacji książki, mające być uzupełnieniem kolekcji, odwiedzał placówkę, czym niekiedy wprawiał w konfuzję jej kierownika. Owocne, ale i trudne relacje obrazuje fragment zapisu z regularnie prowadzonej sprawozdawczości Michałowskiego, wysyłanej do prezesa PAU Stanisława Kutrzeby. W korespondencji z Michałowskim, A. Gubrynowicz często dopytywał o podejmowane działania biblioteczne, z czasem wykazując się rosnąca irytacją z powodu opieszałości w działaniach bibliotecznych. Mimo iż Michałowski wyjaśniał przyczyny opóźnień udostępnienia księgozbioru i okoliczności innych perturbacji (czytając jego listy w innych sprawach, można przypuszczać, że obszernie i wyczerpująco), Adam dopominał się, nierzadko sugerując określone rozwiązania. Tak było w przypadku broszur, które nie od razu zostały włączone do kolekcji, a ich zespolenia w jednej sali magazynowej domagał się A. Gubrynowicz. Oferował przy tym pokrycie kosztów tych $\operatorname{prac}^{48}$. W tym kontekście dziwić tylko trochę może powolność prac w Stacji i aż kilkuletni proces udostępnienia kolekcji dla czytelników. Ma ona jednak swoje obiektywne przyczyny, co do których nie wiemy, czy A. Gubrynowicz dokładnie zdawał sobie sprawę. Należy pamiętać o permanentnych trudnościach lokalowych Stacji. Samo formalne określenie lokalizacji kolekcji B. Gubrynowicza zajęło zatem pięć lat. Dopiero pismem z 1 września 1939 r. adresowanym do władz PAU oraz Adama Gubrynowicza Michałowski poinformował, że wydzielił osobne pomieszczenie pod otrzymany księgozbiór, który miał stanowić odrębną całość ${ }^{49}$. Prace nad ułożeniem księgozbioru zakończyły się na kilkanaście dni przed wybuchem wojny ${ }^{50}$.

\section{Podsumowanie}

Wiemy ze wspomnień osób współpracujących z B. Gubrynowiczem, że użyczał on własną bibliotekę studentom i uczniom. Obecnie biblioteka Gubrynowicza jest niedostępna oczom czytelników Stacji. Zgodnie z częściowo zrealizowaną wolą wdowy po profesorze, znajduje się w wydzielonym pomieszczeniu (na kondygnacji pod czytelnią), do którego wiodą drzwi z widniejącą na nich słabo już połyskującym mosiężnym szyldzikiem „Bibljoteka Profesora Bronisława Gubrynowicza". Jedynym widocznym dla czytelników śladem po Gubrynowiczu jest wiszący na ścianie czytelni odlew z tablicy pamiątkowej barona Bronisława Gubrynowicza, dłuta Jana Nalborczyka. Oryginał znajduje się w kościele św. Marii Magdaleny we Lwowie. Płaskorzeźba w tych dwóch lokalizacjach symbolicz-

${ }^{47}$ ASN PAN, zespół: Korespondencja Stacji 1938-1940, List A. Gubrynowicza do J. Michałowskiego z dn. 10.01.1935.

${ }^{48}$ ASN PAN, zespół: Korespondencja Stacji 1938-1940, List A. Gubrynowicza do J. Michałowskiego z dn. 8.04.[1939?].

${ }^{49}$ ASN PAN, zespół: Korespondencja Stacji 1938-1940, Nr 106/39, Odpis pisma J. Michałowskiego z dn. 1.09.1939.

${ }^{50}$ ASN PAN, zespół: Korespondencja Stacji 1938-1940, Odpis pisma J. Michałowskiego z dn. 26.07.1939. 
nie odmalowuje naukowe życie B. Gubrynowicza, dając jemu klamry: tam gdzie się zaczęło i gdzie znalazło swój spoczynek.

\section{BIBLIOGRAFIA}

\section{Źródla}

Archiwum Nauki PAN i PAU w Krakowie (AN PAU)

sygn. Nr I-135, Zespół: Stacja Naukowa PAN w Rzymie.

Archiwum Stacji Naukowej PAN w Rzymie (ASN PAN)

Szabat Anna, Biblioteka Stacji Naukowej Polskiej Akademii Nauk w Rzymie, Łódź 1996, s. 53, mps. (praca magisterska pod kier. prof. dr hab. B. Sordylowej).

Wronikowska Dominika, Fototeka Karola Lanckorońskiego w Stacji Naukowej PAN w Rzymie, Rzym 2004.

Zespół: Inwentarz Bibljoteki Daru Bronisława Ludwika Gubrynowicza, k. 119.

Zespół: Inwentarz Bibljoteki Bronisława Gubrynowicza, zeszyty 1-5.

Zespół: Korespondencja Stacji 1936-1937.

Zespół: Korespondencja Stacji 1938-1940.

Zespół: Korespondencja z Sekretarzem Generalnym PAU 1934.

Zespół: Teczka inwentarzowa.

\section{Opracowania}

Biliński Bronisław, Biblioteca e Centro di Studi a Roma dell'Accademia Polacca delle Scienze nel 50 Anniversario della Fondazione, 1927-1977, Wrocław 1977.

Biogramy uczonych polskich: materiały o życiu i działalności członków AU w Krakowie, TNW, PAU, PAN: Cz. I: Nauki spoteczne, z. 1: A-J, opr. A. Śródka, P. Szczawiński, Wrocław 1983.

Brochocka Zofia, Profesor Bronisław Gubrynowicz w Uniwersytecie Warszawskim, „Ruch Literacki”, 5-6 (1933) s. 108-109.

Członkowie Akademii Umiejętności oraz Polskiej Akademii Umiejętności: 1872-1952, opr. E. H. Nieciowa, Wrocław 1973.

Dybiec Julian, Polska Akademia Umiejętności: 1872-1952, Kraków 1993.

Grzegorczyk Piotr, Bibljografja prac Prof. Bronisława Gubrynowicza, „Ruch Literacki”, 5-6 (1933) s. 114-128.

Łempicki Zygmunt, Twórczość naukowa Bronisława Gubrynowicza na tle epoki, „Ruch Literacki”, 5-6 (1933) s. 97-101.

Łempicki Zygmunt, Zmarli członkowie: ś.p. Bronisław Gubrynowicz (1870-1933), „Rocznik Towarzystwa Naukowego Warszawskiego", 27 (1934), s. 147-148.

Marciniak Ryszard, Zbiór rzymski i paryski w Bibliotece Kórnickiej, „Pamiętnik Biblioteki Kórnickiej", 15 (1980) s. 261-266.

Rederowa Danuta, Polska Stacja Naukowa w Rzymie, „Rocznik Polskiej Akademii Umiejętności”, 1992/1993 (1994) s. 188-234. 
Piskurewicz Jan, Ośrodki upowszechniania nauki polskiej we Włoszech 1918-1939, „Kwartalnik Historii Nauki i Techniki”, 2 (1995) s. 57-70.

Seroka Katarzyna, Stacja Naukowa Polskiej Akademii Nauk w Rzymie, „Przegląd Polsko-Polonijny", 4 (2012) z. 1, s. 157-168.

Starnawski Jerzy, Piotr Grzegorczyk (17 listopada 1894-20 maja 1968), „Pamiętnik Literacki", 2 (1969) s. 409-415.

Żaboklicki Krzysztof, 75-lecie Stacji Naukowej w Rzymie, „Nauka”, 2 (2003) s. 152-157.

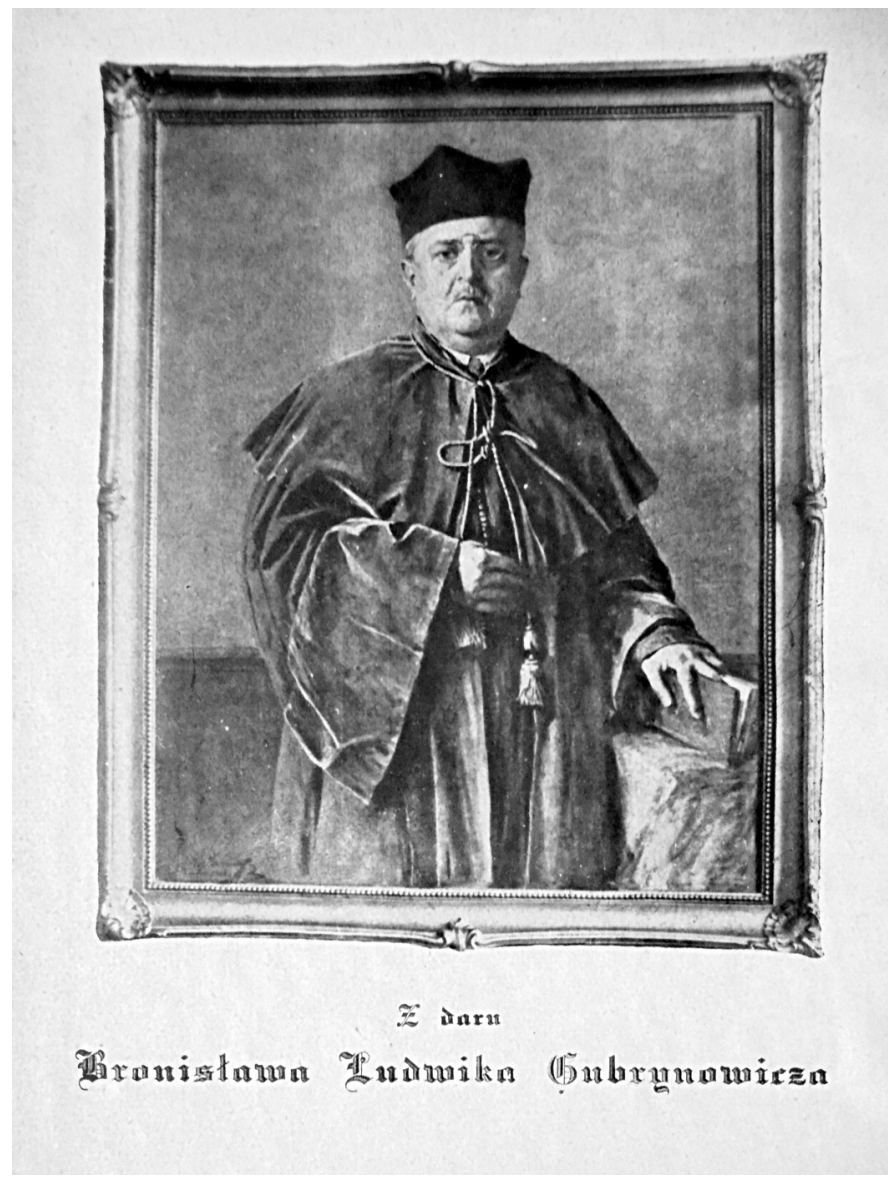

il. 1. Ekslibris portretowy Gubrynowicza ufundowany przez rodzinę po śmierci uczonego (SN PAN w Rzymie). 


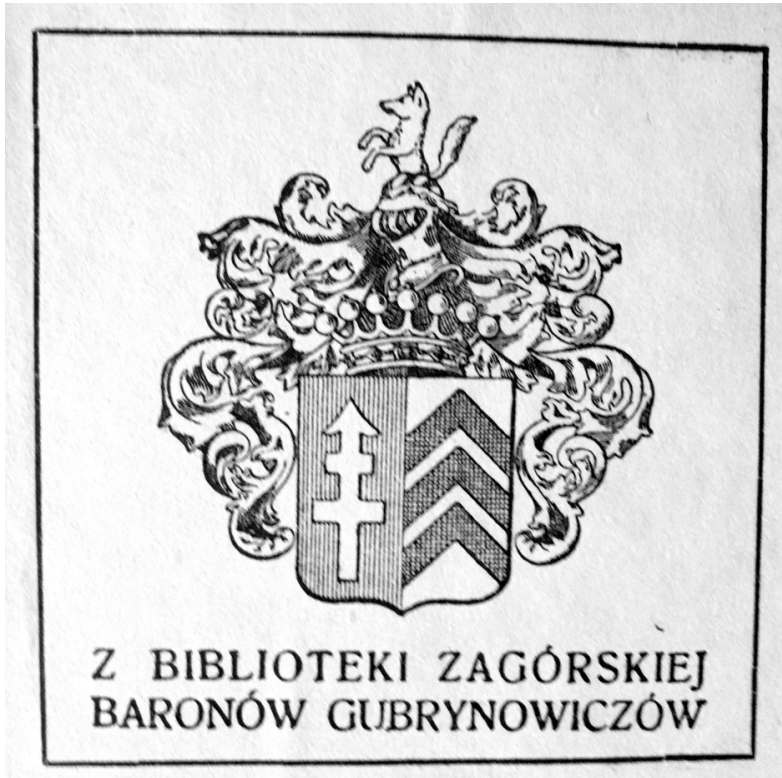

il. 2. Ekslibris biblioteki Gubrynowicza (SN PAN w Rzymie).

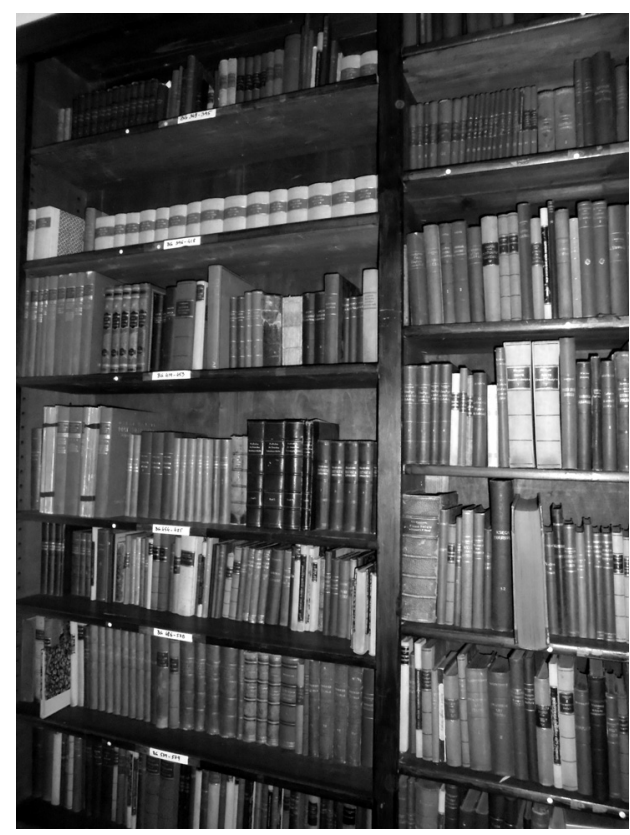

il. 3. Fragment kolekcji umieszczonej w pierwotnym przedwojennym regale (SN PAN w Rzymie). 


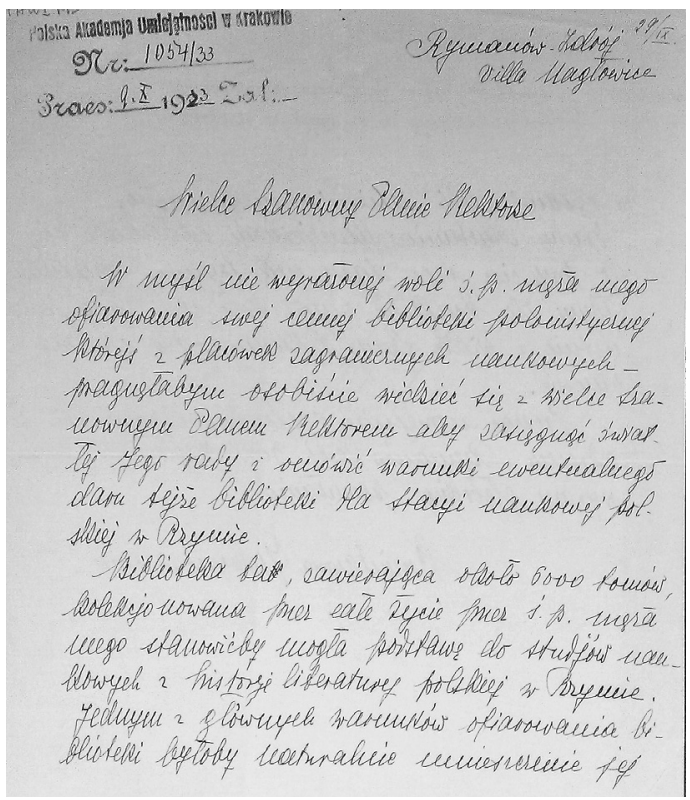

il. 4. Fragment listu H. Gubrynowiczowej do S. Kutrzeby $\mathrm{z}$ informacją o planowanym darze (Biblioteka Naukowa PAU i PAN w Krakowie).

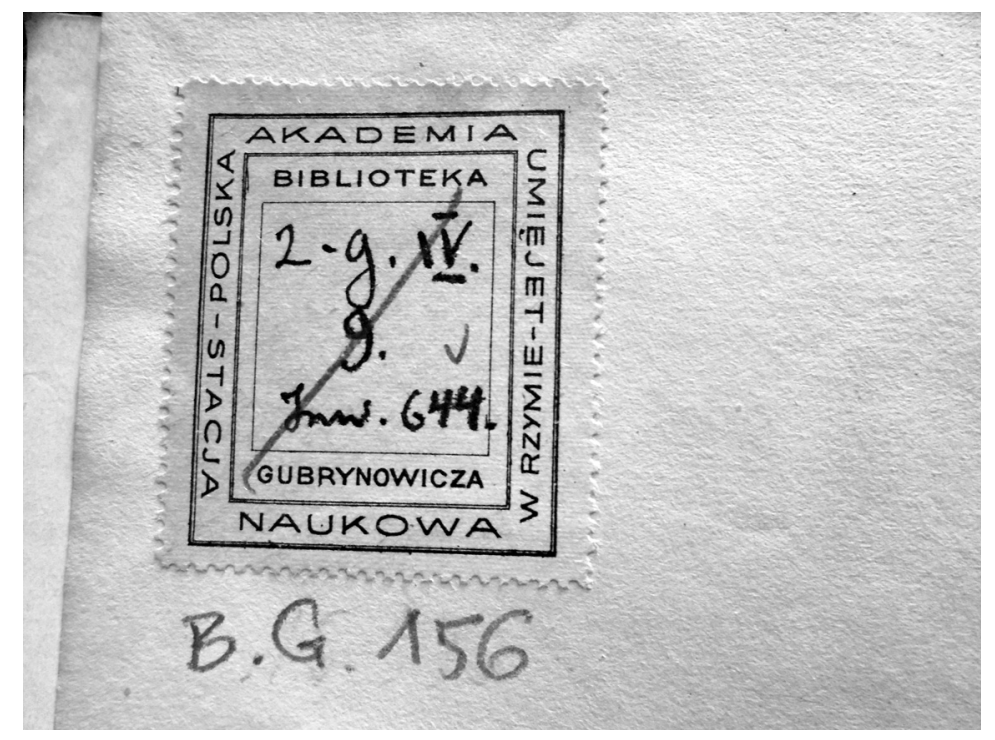

il. 5. Przedwojenna nalepka biblioteczna i współczesna korekta sygnatury (ołówkiem) (SN PAN w Rzymie). 


\title{
BRONISLAW GUBRYNOWICZ I UFORMOWANIE JEGO WARSZTATU BADAWCZEGO W STACJI NAUKOWEJ PAN W RZYMIE
}

\begin{abstract}
Streszczenie
W artykule podjęto próbę charakterystyki tzw. biblioteki Gubrynowicza, należącej do profesora Bronisława Gubrynowicza, który w zapisie testamentowym przekazał prywatną kolekcję pod opiekę i w użytkowanie Stacji Rzymskiej Polskiej Akademii Umiejętności (obecnie PAN) Ten zasób naukowy i warsztat pracy uczonego nie był dotąd przedmiotem żadnych opracowań naukowych. W tekście dokonano krótkiej charakterystyki zbiorów oraz ich losów od śmierci Gubrynowicza do otwarcia biblioteki dla publiczności w 1939 r.

Słowa kluczowe: Bronisław Gubrynowicz; Polska Akademia Umiejętności; Stacja Polska

PAN w Rzymie

\section{BRONISLAW GUBRYNOWICZ AND THE FORMATION OF HIS RESEARCH COLLECTION IN THE RESEARCH CENTRE OF THE POLISH ACADEMY OF SCIENCES IN ROME}

\begin{abstract}
Summary
The article attempts to characterise so-called Gubrynowicz's library, which belonged to Professor Bronisław Gubrynowicz, who in his will bequeathed his it to the Research Centre of the Polish Academy of Learning in Rome (currently the Polish Academy of Sciences). This research resource has not been studied so far. The text includes a brief analysis of the collection and its history from the death of Gubrynowicz to the opening of the library for the public in 1939.
\end{abstract}

Keywords: Bronisław Gubrynowicz; the Polish Academy of Learning; the Research Centre of the Polish Academy of Sciences in Rome 